FITRAH Jurnal Kajian Ilmu-ilmu Keislaman

Vol. 03 No. 1 Juni 2017

e-ISSN : 2460-2345, p-ISSN: 2442-6997

Web: jurnal.iain-padangsidimpuan.ac.id/index.php/F

\title{
STRATEGI PENDIDIKAN ISLAM DI ERA DIGITAL
}

\author{
NURYADIN \\ Institut Agama Islam Negeri Palangka Raya \\ Email: yadinnur5@gmail.com
}

\begin{abstract}
This paper aims to present the strategy of Islamic education in the digital era. The digital era has brought about many changes in various aspects of human life, including in Islamic education. Islamic education as a subsystem of national education needs to deal with and implement the comprehensive measures and sustainable, in scrutinizing the various opportunities and challenges of the digital era in order to establish the existence and role to give birth to a superior generation in intellectual, spiritual, moral, and social as well as creative.
\end{abstract}

Keywords: Islamic education, digital era, education strategy

\section{Abstrak}

Tulisan ini berupaya menyajikan strategi pendidikan Islam di era digital. Era digital telah membawa banyak perubahan dalam berbagai aspek kehidupan manusia, termasuk dalam pendidikan Islam. Pendidikan Islam sebagai subsistem pendidikan nasional perlu menyiasati dan menerapkan langkah-langkah yang komprehensif serta berkesinambungan, dalam mencermati berbagai peluang dan tantangan era digital guna mengukuhkan eksistensi serta perannya dalam melahirkan generasi yang unggul secara intelektual, spiritual, moral, dan sosial serta kreatif.

Kata kunci: pendidikan Islam, era digital, strategi pendidikan

\section{PENDAHULUAN}

Dunia tengah berada di dalam suatu era kemajuan yang dihubungkan oleh teknologi serta perangkat komunikasi dan informasi berbasis digital. Era tersebut tak lain adalah era digital. Era digital bisa dimaknai sebagai suatu keadaan di mana penggunaan perangkat komunikasi dan informasi berbasis digital (internet) $^{1}$ semakin masif dan mendominasi berbagai aktivitas keseharian

1 Menurut Randall dan Latulipe, internet merupakan singkatan dari interconnection networking, yang berarti a global network of computer networks. Makna lainnya, internet merupakan kumpulan luas dari jaringan komputer yang saling terhubung di seluruh dunia, mulai dari komputer kecil (personal computer) di rumah-rumah sampai komputer besar di perusahaanperusahaan. Fungsi internet adalah sebagai media komunikasi dan pertukaran informasi. Lihat Fandy Tjiptino dan Totok Budi Santoso, Strategi Riset Lewat Internet, (Yogyakarta: Andi, 2010), hlm. 2. Lihat juga Deni Darmawan, Pendidikan Teknologi Informasi dan Komunikasi, (Bandung: Remaja Rosdakarya, 2013), cet ke-2, hlm. 97. 
FITR AH Jurnal Kajian Ilmu-ilmu Keislaman

Vol. 03 No. 1 Juli 2017

manusia, mulai dari kegiatan ekonomi, kesenian, olahraga, pemerintahan, pendidikan, sosial, dan lain sebagainya.

Era digital telah merasuk ke berbagai kawasan negara-negara di dunia. Semua saling terhubung satu sama lain. Seakan tiada batas yang menjadi sekat (borderless). Segala informasi terbuka yang ada dalam suatu kawasan dapat diketahui seketika juga oleh penduduk di kawasan lain. Semua itu terjadi karena hadirnya era digital yang telah menggantikan dominasi era konvensional. Era digital sendiri terlahir dari rahim serta pesatnya perkembangan era global atau globalisasi. ${ }^{2}$

Dalam era global keadaan dunia menurut seorang futurolog terkenal, Alvin Toffler, bergerak memasuki dunia baru yang dikenal dengan istilah The Third Wave (Gelombang Ketiga), yakni gelombang peradaban dengan merambahnya teknologi informasi, komputerisasi, revolusi biologi, teknologi perang dan terorisme, dan lain-lain yang bersifat global. ${ }^{3}$

Di era itulah perkembangan teknologi dan perangkat digital semakin canggih dan terus dikembangkan serta diperbarui. Gelombang peradaban tersebut membuat manusia tidak terlepas dari produk-produk digital. Bahkan semuanya kian terhubung, terbuka dan saling ketergantungan. Meski tetap memiliki wilayah teritorial dan garis pemisah yang jelas secara geografis, namun batas-batas tersebut tak menjali tirai penghalang untuk berinteraksi, berkomunikasi dan berbagi informasi secara terbuka oleh masyarakat digital.

Dukungan penggunaan perangkat digital yang masif telah memudahkan orang-orang dengan latar beragam untuk berinteraksi di dunia maya. Dunia maya menjadi wujud nyata keterbukaan individu-individu di berbagai belahan dunia. Kemunculan dan kehadiran era digital dewasa ini merupakan sesuatu yang tidak bisa dielakkan oleh negara manapun di dunia ini, termasuk oleh

${ }^{2}$ Era globalisasi merupakan suatu keadaan yang ditandai oleh adanya penyatuan politik, ekonomi, sosial, budaya, ilmu pengetahuan, teknologi, informasi, dan lain sebagainya yang terjadi antara satu negara dengan negara lainnya, tanpa menghilangkan identitasnya masing-masing. Lihat Abuddin Nata, Kapita Selekta Pendidikan Islam, (Jakarta: RajaGrafindo Persada, 2012), cet ke-1, hlm. 10.

${ }^{3}$ Ahmad Arifi, Politik Pendidikan Islam: Menelusuri Ideologi dan Aktualisasi Pendidikan Islam di Tengah Arus Globalisasi, (Yogykarta: Penerbit Teras, 2010), cet ke-1, hlm. 135-136. Menurut Azra, globalisasi yang tengah mewabah di berbagai dunia termasuk di Indonesia menampilkan sumber dan sifat yang berbeda. Globalisasi ini tidak lagi bersumber dari Timur Tengah, melainkan dari Barat, yang terus memegang supremasi dan hegemoni dalam berbagai lapangan kehidupan masyarakat dunia. Globalisasi Barat tampil dengan watak ekonomi-politik dan sains-teknologi. Lihat Azyumardi Azra, Pendidikan Islam: Tradisi dan Modernisasi di Tengah Tantangan Milenium III, (Jakarta: Kencana, 2012), cet ke-1, hlm. 41-42. 
pendidikan Islam itu sendiri. Pendidikan Islam yang secara normatif dipandang sebagai pendidikan ideal dengan memadukan konsep keseimbangan duniawi dan ukhrawi berbasis pada landasan wahyu (al-Quran dan hadis) serta ijtihad (kreasi pemikiran dalam Islam) nyatanya kian membutuhkan kehadiran perangkat digital. Tujuannya tidak lain adalah memudahkan berbagai aktivitas maupun program pendidikannya baik pada tataran perencanaan, pelaksanaan maupun evaluasi.

Sebagai sebuah keniscayaan akan hadirnya era digital, pendidikan Islam dituntut mampu beradaptasi atau menyesuaikan diri agar tidak tertinggal jauh dari pendidikan model lainnya. Pendidikan Islam dengan segala sumber dayanya diharapkan dapat memanfaatkan peluang era digital guna mengukuhkan eksistensinya sebagai pionir pendidikan yang unggul dan bermutu, baik dalam konteks keindonesiaan maupun dalam kancah peradaban global.

Selain itu penting pula mengedepankan langkah-langkah strategis dalam melihat peluang serta kesempatan yang ditawarkan di era ini. Tentunya langkah dan strategi yang diambil tidak parsial dan bersifat jangka pendek, melainkan dirancang lebih komprehensif dan bersifat terpadu. Strategi yang ditetapkan hendaknya meliputi berbagai aspek mulai dari perencanaan, pengorganisasian, pelaksanaan, pengawasan hingga evaluasi dengan melibatkan berbagai komponen dalam sistem pendidikan Islam seperti tujuan, sumber daya manusia, kurikulum, lingkungan, evaluasi, dan berbagai komponen lainnya.

Sehingga dengan merancang dan menerapkannya secara tepat pendidikan Islam mampu tampil dengan segala keunggulan sumber daya yang dimilikinya. Dengan kata lain pendidikan Islam ditantang untuk dapat menghasilkan lulusan yang memiliki keunggulan atau kompetensi knowledge, skill, dan personality.4 Karena pendidikan Islam dalam makna yang luas adalah segala usaha untuk memelihara dan mengembangkan fitrah manusia serta SDM yang ada padanya menuju terbentuknya manusia seutuhnya sesuai dengan norma-norma Islam, sehingga menjadi hamba Allah yang sebenar-benarnya dan mampu berperan sebagai khalifah Allah. ${ }^{5}$

${ }^{4}$ Jejen Musfah (ed.), Pendidikan Holistik: Pendekatan Lintas Perspektif, (Jakarta: Kencana, 2012), cet ke-1, hlm. 376 .

${ }^{5}$ Achmadi, Ideologi Pendidikan Islam: Paradigma Humanisme Teosentris, (Yogyakarta: Pustaka Pelajar, 2008), cet ke-2, hlm. 179. 
FITR AH Jurnal Kajian Ilmu-ilmu Keislaman

Vol. 03 No. 1 Juli 2017

\section{PEMBAHASAN}

\section{Peluang Dan Tantangan Era Digital}

Era digital membawa dampak yang begitu besar bagi kehidupan umat manusia dewasa ini. Banyak sektor kehidupan yang mengalami perubahan dan kemajuan berkat teknologi yang dihadirkan di era ini. Pendidikan Islam sebagai subsistem pendidikan nasional juga tak bisa dilepaskan begitu saja dari keberadaan dan pengaruh teknologi informasi dan komunikasi (information and communication technology) di era digital.

Bahkan keterlibatan teknologi informasi dan komunikasi dalam dunia pendidikan saat ini bukan lagi sebuah pilihan, melainkan kebutuhan mutlak yang mesti dimiliki dan dimanfaatkan perguruan tinggi (termasuk lembaga pendidikan jenjang lainnya, dari penulis) jika ingin meningkatkan penyelenggaraan pendidikannya. ${ }^{6}$ Atas dasar hal tersebut, maka pendidikan Islam mesti segera berbenah dan menyiapkan dirinya untuk terlibat aktif di dalamnya.

Banyak peluang dan tantangan yang muncul di era ini. Peluang-peluang yang ditawarkan sejatinya dapat menjadi modal dan kesempatan berharga bagi pendidikan Islam agar dapat menampilkan dirinya sebagai sebuah keunggulan di tengah-tengah aneka peradaban global. Sementara tantangan dapat dilihat sebagai pijakan untuk mengeksplorasi kelebihan yang dimiliki sekaligus mengevaluasi berbagai kekurangan yang selama ini melingkupi pendidikan Islam.

Peluang besar yang ditawarkan pada era ini khususnya bagi perkembangan dan kemajuan dunia pendidikan Islam di antaranya adalah terbukanya informasi bagi masyarakat guna mengakses informasi pendidikan serta programnya, kesempatan untuk berkiprah secara optimal dalam berbagai bidang, saling terbukanya kesempatan untuk meningkatan kerja sama dengan berbagai lintas instansi, dan lain sebagainya.

Tantangan yang dihadapi oleh pendidikan Islam seperti disebutkan sebelumnya beragam dan bervariasi, baik berupa tantangan internal maupun eksternal. Di antara tantangan-tantangan internal yang dihadapi pendidikan

${ }^{6}$ Ricardus Eko Indrajit dan Ricardus Djikopranoto, Manajemen Perguruan Tinggi Modern, (Yogyakarta: CV. ANDI OFFSET, 2006), hlm. 339. Teknologi informasi dan komunikasi merupakan semua teknologi yang berhubungan dengan pengambilan, pengumpulan (akuisisi), pengolahan, penyimpanan, penyebaran, dan penyajian informasi. Lihat Deni Darmawan, Teknologi Pembelajaran, (Bandung: Remaja Rosdakarya, 2012), hlm. 1. 
Islam, menurut Arifi, yaitu orientasi dan tujuan pendidikan, pengelolaan (manajemen), dan hasil (out put). ${ }^{7}$ Tilaar menyebutkan tantangan utama pendidikan adalah kualitas. ${ }^{8}$

Sedangkan tantangan eksternal yang muncul adanya pertarungan ideologiideologi besar dunia. ${ }^{9}$ Selain itu juga menghadapi berbagai kecenderungan (tantangan) yang menurut Daniel Bell ditandai dengan lima hal yaitu,

1. Kecenderungan integrasi ekonomi yang menyebabkan terjadinya persaingan bebas dalam dunia pendidikan.

2. Kecenderungan fragmentasi politik yang menyebabkan terjadinya peningkatan tuntutan dan harapan dari masyarakat. Hal ini bisa dijumpai dalam pendidikan Islam seperti model pembelajaran yang akomodatif dan partisipatoris.

3. Kecenderungan penggunaan teknologi canggih (sofisticated technology) khususnya teknologi komunikasi dan informasi seperti komputer. Pendidikan Islam tak ketinggalan untuk memanfaatkan kemajuan teknologi tersebut dalam urusan pendidikannya.

4. Kecenderungan interdependency (kesalingtergantungan), yaitu suatu keadaan di mana seseorang baru dapat memenuhi kebutuhannya apabila dibantu oleh orang lain. Pendidikan Islam memiliki ketergantungan pada tuntunan masyarakat dan pengguna lulusan.

5. Kecenderungan munculnya penjajahan baru dalam bidang kebudayaan (new colonization in culture) yang mengakibatkan terjadinya pola pikir (mindset) masyarakat pengguna pendidikan, yaitu dari yang semula mereka belajar dalam rangka meningkatkan kemampuan intelektual, moral, fisik dan psikisnya, berubah menjadi belajar untuk mendapatkan pekerjaan dan penghasilan yang besar. ${ }^{10}$

Tentunya berbagai tantangan di atas menjadi ujian bagi pendidikan Islam. Apakah mampu menghadapinya ataukah justru sebaliknya? Oleh karena itu,

\footnotetext{
${ }^{7}$ Ahmad Arifi, Politik Pendidikan...,hlm. 144.

8 Haidar Putra Daulay, Pendidikan Islam dalam Sistem Pendidikan Nasional di Indonesia, (Jakarta: Kencana, 2012), cet ke-3, hlm. 170.

9 Ideologi-ideologi yang dimaksud adalah kapitalisme, materialisme, naturalisme, pragmatisme liberalisme bahkan ateisme yang secara keseluruhan berpusat pada kesadaran manusia (anthrocentris). Berbeda dengan karakteristik keseimbangan ajaran Islam yang memadukan antara berpusat pada manusia (antrhopocentris) dan berpusat pada Tuhan (theocentris). Lihat Abuddin Nata, Kapita Selekta..., hlm. 13.

${ }^{10}$ Ibid.,hlm. 14-17.
} 
FITR AH Jurnal Kajian Ilmu-ilmu Keislaman

Vol. 03 No. 1 Juli 2017

dibutuhkan formula dan strategi menyeluruh dalam melihat peluang serta tantangan besar di era serba digital saat ini. Pendidikan Islam tidak boleh menutup mata apalagi mengabaikan hal tersebut, karena secara perlahan atau secepatnya, perubahan zaman akan terus terjadi dan perkembangan digital akan berlansung pesat, yang berpengaruh besar bagi peradaban dunia.

\section{Problematika Pendidikan Islam Dewasa Ini}

Meskipun pendidikan Islam dipandang begitu ideal dengan landasan dari al-Quran dan hadis serta pemikiran-pemikiran inspirasional para filosof, intelektual dan mujtahid, namun dalam realitasnya dewasa ini masih terdapat berbagai problem yang melingkupinya. Hal tersebut secara jelas berdampak secara langsung pada rendahnya kualitas umat Islam yang dilahirkan dari rahim lembaga-lembaga pendidikan Islam. Yang pada saat yang sama juga memicu terpinggirkannya umat Islam dalam percaturan dan peta kontestasi global.

Problematika yang dihadapi oleh pendidikan Islam tidak tunggal dan parsial. Bisa dibilang problematika yang merudung keberadaan pendidikan Islam saat ini berkaitkelindan sehingga nampak kusut. Ada sejumlah problem atau masalah yang masih membelit yang saling terkait satu sama lain. Menurut Achmadi problem utama pendidikan nasional, termasuk pendidikan Islam, adalah kualitas pendidikan yang rendah yang memicu rendahnya kualitas SDM. Rendahnya kualitas SDM berimbas pada rendahnya karakter bangsa. ${ }^{11}$ Problem lain yang dihadapi oleh pendidikan Islam seperti problem ideologis, dualisme sistem pendidikan Islam, bahasa, dan problem metode pembelajaran. ${ }^{12}$

Problem ideologis menyangkut lemahnya inisiatif dan komitmen sebagian umat Islam dalam menghubungkan penguasaan ilmu pengetahuan dengan kemajuan-kemajuan. Akibatnya semangat dalam menuntut ilmu, utamanya ilmu pengetahuan sains, belum menjadi kultur di kalangan mayoritas umat Islam. Pemahaman Islam yang reduktif dan parsial menjadi pemicu mengapa penguasaan ilmu pengetahuan tidak mendapat tempat yang utama. Problem ideologis ini begitu akut yang berdampak pada rendah serta tidak meratanya kualitas generasi kaum muslim.

Problem dualisme sistem pendidikan Islam bersangkutpaut dengan kebijakan. Kebijakan mengenai pendidikan (Islam) diatur dan dikelola oleh

${ }^{11}$ Achmadi, Ideologi Pendidikan..,hlm. 162.

12 S. Lestari dan Ngatini, Pendidikan Islam Kontekstual, (Yogyakarta: Pustaka Pelajar, 2010), cet ke-1, hlm. 84 . 
instansi terkait serta instansi di bawahnya. Di tanah air, pendidikan Islam bernaung di bawah wewenang dan otoritas Kementrian Agama (Kemenag) sementara pendidikan umum bernaung di bawah Kementrian Pendidikan dan Kebudayaan (Kemdikbud). Ada pula Kementrian Riset Teknologi dan Pendidikan Tinggi (Kemenristekdikti) yang menaungi lembaga pendidikan tinggi/perguruan tinggi umum maupun agama. Instansi-instansi di atas mempunyai wewenang mengelola lembaga pendidikannya masing-masing. Dualisme pengelolaan pendidikan Islam oleh Kemenag dan Kemdikbud masih mewarnai perjalanan pendidikan Islam, meskipun saat ini terdapat upaya untuk menjembatani problem tersebut.

Permasalah bahasa juga mendera sebagian lembaga pendidikan Islam di tanah air, terutama penguasaan bahasa asing, baik bahasa Arab, bahasa Inggris ataupun bahasa asing lainnya. Kemampuan SDM (pendidik dan tenaga kependidikan) dalam menguasai bahasa asing masih rendah serta belum merata. Padahal penguasaan bahasa asing sangat penting dalam mengakses berbagai informasi, dan ilmu pengetahuan dan teknologi yang berkembang. Problem kebahasaan ini mesti dituntaskan agar akses dan kesempatan untuk mendapatkan informasi dan pengetahuan semakin terbuka bagi pengembangan dan peningkatan kualitas SDM maupun lembaga pendidikan Islam.

Aspek pembelajaran dalam pendidikan Islam juga mengalami masalah terutama dari sisi metode yang digunakan. Selama ini pendidikan Islam mulai tingkat dasar hingga menengah, tidak menutup kemungkinan pada tingkat pendidikan tinggi juga dijumpai dominan atau menonjolnya metode satu arah yang cenderung monoton. Pendidik (guru atau dosen) dianggap mempunyai peran dominan dalam proses pembelajaran di kelas, dan kurang memberikan ruang dan kesempatan bagi peserta didik untuk berkembang karena penggunaan metode pembelajaran yang satu arah tadi. Misalnya penggunaan metode ceramah yang mengambil porsi banyak dibandingkan metode lain yang bersifat interaktif, dialogis, dinamis dan kritis.

Problem lain yang juga mengemuka pada masyarakat modern adalah munculnya praktek-prakter pereduksian fungsi pendidikan. Pendidikan hanya distandarkan pada upaya-upaya penyiapan tenaga kerja (praktisi) yang berorientasi materialistik, dengan dalih untuk mendukung industrialisasi modern dan pemenuhan kebutuhan-kebutuhan kuantitas besar produk-produk 
FITR AH Jurnal Kajian Ilmu-ilmu Keislaman

Vol. 03 No. 1 Juli 2017

teknologi. ${ }^{13}$ Kondisi ini ditambah dengan kurang atau tidak relevannya pendidikan dengan kebutuhan masyarakat. Problem relevansi semakin membuat pendidikan Islam nampak dilematis.

Penguasaan atau kurang melek terhadap perangkat teknologi informasi dan komunikas juga menjadi problem yang mencuat dalam pendidikan Islam. Lemahnya aspek ini berpengaruh pada kemampuan dalam mengakses berbagai informasi dan kemajuan penting dalam dunia pendidikan secara khusus dan kemajuan dunia secara umum. Hal tersebut jelas akan mengakibatkan lemahnya kualitas SDM.

\section{Langkah-Langkah Strategis Pendidikan Islam}

Guna mengurai benang kusut pendidikan Islam pada tingkat gagasan, kebijakan, dan operasionalnya, perlu dirancang dan disusun langkah-langkah strategis. Karena untuk mengurai benang kusut dan menjalinnya lebih erat serta indah diperlukan strategi yang menyeluruh. Tidak hanya pada aspek hilirnya semata, namun ditekankan pula pada aspek hulu yang menjadi sumber atau sebabnya.

Pendidikan Islam dalam kehidupan global dituntut menjadi kawah candradimuka dalam pengembangan masyarakat Islam. Seperti ditekankan oleh Arifi bahwa pendidikan Islam mempunyai peranan kunci bagi kontinuitas atau keberlanjutan Islam. Selain juga menentukan karakter dari masyarakat muslim. ${ }^{14}$

Berdasarkan pernyataan tersebut serta untuk menjawab berbagai tantangan di atas, pendidikan Islam membutuhkan SDM yang handal, memiliki komitmen dan etos kerja yang tinggi, manajemen yang berbasis sistem dan infrastruktur yang kuat, sumber dana yang memadai, kemauan politik yang kuat, serta standar yang unggul. ${ }^{15}$ Diperlukan strategi solutif untuk meningkatkan kiprah pendidikan Islam di era serba digital ini, agar survive dan mampu menjadi salah satu alternatif pemecahan masalah atas berbagai problem kemanusiaan.

\section{Pengembangan dan Peningkatan Kualitas Sumber Daya Manusia}

Peningkatan kualitas SDM merupakan keharusan bagi bagi pendidikan Islam dalam mengarungi era digital. Kualitas SDM akan berdampak besar pada peningkatan kualitas pendidikan Islam, baik untuk kelembagaan maupun aspek

\footnotetext{
${ }^{13}$ Ahmad Arifi, Politik Pendidikan..., hlm. 135.

${ }^{14}$ Ibid., hlm. 137.

${ }^{15}$ Abuddin Nata, Kapita Selekta..., hlm. 18.
} 
lainnya. SDM dengan kemampuan, keahlian dan profesional yang mumpuni diharapkan dapat mengembangkan pendidikan Islam agar lebih optimal dengan segala sumber daya yang tersedia.

Kualitas SDM yang dimaksud berkaitan erat dengan kompetensi teknis dan nonteknis. Kompetensi teknis meliputi kemampuan, keahlian, dan profesionalitas yang menjadi prasyarat mutlak untuk mencapai kemampuan daya saing bangsa di era global. Sementara kecakapan nonteknis meliputi nilai dan perilaku modern serta kreativitas yang akan berdampak sangat besar terhadap produktivitas. ${ }^{16}$

SDM dalam konteks ini mencakup pimpinan, pendidik, tenaga kependidikan, dan staf/karyawan serta peserta didik. Kualitas SDM yang diinginkan adalah mampu dan terampil dalam menjalankan tugas dan wewenangnya. Keahlian dan profesionalitas dalam menjalankan tanggung jawab sangat dituntut dan menjadi sebuah kemutlakan. Jika institusi pendidikan Islam tidak memiliki SDM yang cakap dan handal, bukan tak mungkin program serta aktivitas institusinya tidak berjalan optimal. Yang lebih dikhawatirkan adalah lahirnya lulusan yang tidak menguasai apa yang menjadi bidangnya serta kalah bersaing di berbagai lapangan kehidupan.

Bagi pimpinan, pendidik, dan tenaga kependidikan pada lembaga pendidikan Islam, aspek penting yang perlu ditekankan dalam hubungannya dengan peningkatan kualitas SDM lembaga pendidikan Islam adalah pengetahuan dan wawasan agama yang memadai atau memiliki tingkat melek/literasi keagamaan yang matang, kepemimpinan yang efektif dalam menjalankan roda institusi pendidikan Islam, pemahaman yang mendalam mengenai pendidikan Islam mulai dasar, tujuan, SDM, kurikulum, evaluasi, dan lain-lain, penguasaan bahasa asing (bahasa Arab, Inggris, dan lainnya) dan keterampilan berkomunikasi secara efektif, kemampuan administrasi manajerial atau pengelolaan pendidikan Islam, dan penguasaan terhadap perangkat teknologi informasi dan komunikasi.

Selain pihak-pihak yang terlibat secara langsung dalam pengembangan pendidikan Islam, peserta didik juga menjadi pihak yang mutlak dikembangkan aspek sumber dayanya yaitu potensi jasmani, rohani, dan spiritual. Jika ketiga potensi ini dikembangkan seoptimal mungkin akan lahir insan akademik

16 Ace Suryadi, Pendidikan Indonesia Menuju 2025; Outlook: Permasalahan, Tantangan $\mathcal{E}$ Alternatif Kebijakan, (Bandung, Remaja Rosdakarya, 2014), cet ke-1, hlm. 39. 
FITR AH Jurnal Kajian Ilmu-ilmu Keislaman

Vol. 03 No. 1 Juli 2017

berkualitas dan memiliki keunggulan-keunggulan, yang berpengaruh pada kualitas dan karakter bangsa yang sesuai dengan ajaran agama dan pandangan hidup bangsa.

Di era global dan digital, hanya negara-negara yang memiliki keunggulankeunggulan yang dapat bertahan. Keunggulan-keunggulan yang mutlak dimiliki adalah penguasaan sains-teknologi dan keunggulan kualitas sumber daya manusia. ${ }^{17}$ Oleh karena itu, pendidikan Islam hendaknya menekankan hal tersebut sebagai salah satu prioritas utamanya.

\section{Pengembangan Kurikulum Pendidikan Islam Terpadu}

Kurikulum menurut UU Sistem Pendidikan Nasional No 20 Tahun 2003 bermakna sebagai seperangkat rencana dan pengaturan mengenai tujuan, isi, dan bahan pelajaran serta cara yang digunakan sebagai pedoman penyelenggaraan kegiatan pembelajaran untuk mencapai tujuan pendidikan tertentu. Kurikulum dengan demikian tidak hanya mencakup apa yang selama ini dipahami yakni mata pelajaran, bidang studi, dan mata kuliah, melainkan segala kegiatan yang terdapat dalam penyelenggaraan pendidikan mulai dari penentuan tujuan hingga evaluasi.

Pendidikan Islam yang lahir dari produk serta kreatifitas ajaran Islam menekankan pada keseimbangan dunia dan akhirat. Konsekuensi logis dari hal tersebut adalah tuntunan pada penerapan kurikulum terpadu yang dalam hal ini dimaksud dengan kurikulum pendidikan agama dan pendidikan umum. Pendidikan Islam yang selama ini lebih menekankan dan berorientasi pada ilmuilmu agama belum mampu tampil sebagai pionir perubahan dalam kehidupan sehari-hari, terlebih di era digital sekarang.

Sehingga diperlukan peran dan kontribusi dari ilmu-ilmu yang selama ini dikesankan sekuler, keduniawian yakni ilmu-ilmu umum (sains teknologi dan humaniora). Peran dan perpaduan kedua keilmuan dan corak pendidikan umum dan agama tersebut dipandang mampu dalam menjawab berbagai persoalan kekinian yang begitu kompleks.

Penting pula untuk mengintegrasikan isu-isu kekiniaan dalam kurikulum pendidikan Islam agar dapat memahami perkembangan zaman yang terus bergerak, seperti multikulturalisme, inklusifitas, radikalisme, kewirausahaan,

17 Azyumardi Azra, Pendidikan Islam..., hlm. 44. Lihat juga Muhaimin, Pemikiran dan Aktualisasi Pengembangan Pendidikan Islam, (Jakarta: Rajawali Pers, 2012), cet ke-2, hlm. 92-93. 
dan lain sebagainya. Dengan cara demikian akan terbentuk pemahaman yang luas dalam memandang realitas kehidupan secara integratif.

Pemerintah perlu menyediakan kebijakan dan payung hukum bagi implementasi kurikulum terpadu yang dapat mengakomodasi kepentingan pendidikan Islam guna mendukung dan menyukseskan visi dan misi pendidikan nasional yang telah dicanangkan.

\section{Peningkatan Relasi dan Kerja Sama Pendidikan Islam}

Yang tidak kalah penting juga dalam kehidupan era digital bagi pendidikan Islam adalah menjalin relasi dan meningkatkan kerja sama dengan berbagai institusi pendidikan dan non pendidikan, baik institusi pemerintahan maupun non pemerintahan, dalam dan luar negeri. Kolaborasi dan kerja sama semakin dibutuhkan pada era masa kini, karena adanya salingketergantungan antara satu instanti dengan instansi lainnya. Tantangan yang dihadapi pun sedemikian kompleks.

Kolaborasi dan kerja sama adalah solusi untuk menjawab berbagai tantangan yang dihadapi oleh pendidikan Islam serta sebagai respon di era digital. Apalagi globalisasi menuntut pendidikan Islam agar responsif dalam menjawab berbagai tantangan dan persoalan kehidupan umat manusia.

Kerja sama dimaksudkan untuk meningkatkan kompetensi SDM, berbagi dan menyerap informasi, dan meningkatkan kapasitas pendidikan Islam itu sendiri, baik dari aspek kelembagaan, kompetensi SDM, kurikulum, program terkait, dan peningkatan infrastruktur pendukung. Kerja sama akan memberikan nilai tambah bagi pendidikan Islam, yang berguna bagi perkembangan pendidikan Islam ke depannya.

\section{Pembenahan Infrastruktur Berbasis Teknologi Digital}

Pembenahan infrastruktur menjadi suatu keniscayaan dalam meningkatkan kualitas pendidikan serta sebagai respon terhadap globalisasi. Utamanya adalah infrstruktur berbasis teknologi digital. Hampir sebagian besar aktivitas pendidikan seperti administrasi manajemen, pembelajaran, dan lainnya, dapat memanfaatkan perangkat teknologi informasi dan komunikasi. Maka ketersediaan fasilitas infrastruktur yang mendukung menjadi jawaban dari tuntutan tersebut.

Pendidikan Islam mesti menyadari urgennya ketersediaan infrastruktur teknologi digital guna memudahkan kegiatan pendidikan. Kerapkali kendala dalam kegiatan pendidikan, pembelajaran, dan administrasi berkaitan dengan 
FITR AH Jurnal Kajian Ilmu-ilmu Keislaman

Vol. 03 No. 1 Juli 2017

tidak atau kurang tersedianya infrastruktur. Inilah yang harusnya dibenahi agar kedepannya pendidikan Islam mampu berbicara lebih baik.

Namun aspek pembiayaan menjadi problem bagi pendidikan Islam dalam menyediakan infrastruktur berbasis teknologi digital. Butuh biaya yang tidak sedikit untuk memenuhinya. Karenanya, diperlukan strategi dan skema pembiayaan yang kompetitif. Pemerintah dan kalangan swasta dalam hal ini dapat diajak bekerjasama untuk menyediakan pembiayaan guna memenuhi ketersediaan infrastruktur yang dibutuhkan di atas.

\section{Pemanfaatan Media Pembelajaran Berbasis Digital}

Dewasa ini pemanfaatan internet sedemikian masif dan telah menjadi kebutuhan serta gaya hidup masyarakat. Pemanfaatan media berbasis digital (internet) tentunya menjadi keniscayaan dalam aktivitas pendidikan dan pembelajaran. Mendidik generasi era digital tidak mungkin hanya mengandalkan media konvensional semata. Diperlukan pemaduan antara media konvensional dan media digital agar hasilnya lebih maksimal.

Seorang pendidik dituntut mampu mendayagunakan dan mengoptimalkan pemanfaatan media digital guna mendukung keberhasilan pendidikan dan pembelajaran. Karena keberhasilan pendidikan dan pembelajaran dalam pendidikan Islam juga dipengaruhi oleh faktor pemanfaatan media yang mendukung dan sesuai dengan konteks pembelajaran.

Berkaitan dengan hal tersebut penting untuk dicermati bahwa di era digital ini generasi manusia terbagi menjadi dua kelompok; digital immigrant, yaitu kelompok yang sejak lahir tidak ada internet pada masanya, yang kemudian muncul dan berkembanglah internet sehingga menjadi aktif di dalamnya, dan digital native, yaitu kelompok yang sedari lahir telah berada dalam era hadirnya internet. Kedua kelompok tersebut sama-sama menggunakan internet untuk kebutuhan interaksinya di dunia maya. ${ }^{18}$

Seorang pendidik harus menyadari realitas generasi digital masa kini yang tidak terlepas dari genggaman gawai (gadget) dan perangkat komputer (personal computer) dalam kesehariannya. Menyikapi hal demikian, seorang pendidik harus mampu menjadi contoh dan memberikan panduan bagi peserta didik

18 Fathoni Ahmad, Tantangan Pendidikan di Era Digital, Bagaimana Menyikapinya?, http://madrasah.kemenag.go.id/didaktika/96/tantangan-pendidikan-di-era-digital-bagaimanamenyikapinya.html, diakses pada 26 Maret 2017. 
dalam memanfaatkan produk digital tersebut secara positif dan diarahkan pada sarana dalam meningkatkan kualitas pembelajaran.

Internet dapat dijadikan sebagai media alternatif untuk memberikan materi belajar (kuliah/sekolah) secara online. Sehingga materi belajar dapat diakses oleh siapapun yang membutuhkan, baik kelas dominan maupun kelas populer. Hal ini sangat membantu bagi mereka yang terkendala ruang dan waktu. ${ }^{19}$

\section{Penerapan Metode Pembelajaran Partisipatoris}

Era digital telah membawa perubahan besar dalam dunia pendidikan Islam. Aktivitas pendidikan semakin efektif dan efisien dengan hadirnya perangkat digital. Dalam kegiatan pembelajaranpun diharapkan terbentuk suatu komunitas yang mampu memanfaatkan perangkat atau media digital dalam mendorong terciptanya pembelajaran berkualitas dan mampu mengakomodasi potensi dan partisipasi peserta didik.

Konteks pembelajaran dengan sistem tatap muka (kelas) yang selama ini berlangsung dapat diperkaya dengan kegiatan pembelajaran berbasis online (elearning) atau pembelajaran elektronik. Apalagi pendidikan di masa mendatang menurut para cendekiawan, lebih bersifat terbuka dan dua arah, beragam, multidisipliner serta terfokus pada produktivitas kerja saat itu dan kompetitif. ${ }^{20}$

Maka menerapkan metode pembelajaran yang partisipatoris atau berpihak pada keragaman dan keunikan peserta didik semakin menemukan momentum dan konteksnya. Strategi dan metode pembelajaran pada masa sekarang tentunya berbeda dengan konteks pembelajaran masa lalu yang cenderung satu arah, monoton, kurang partisipastif, dan kurang apreasiatif terhadap media pembelajaran pendukung, terlebih media digital.

Di sinilah pentingnya menerapkan dan membiasakan metode yang mampu mengaktualisasikan potensi peserta didik. Metode partisipatoris dengan demikian menjadi solusi dalam menjawab kebutuhan partisipasi peserta didik di era global sekarang. Metode partisipatoris yang penting dalam pembelajaran era digital adalah diskusi, tanya jawab, demonstrasi, ceramah interaktif, video call, teleconference, dan lain sebagainya. Penerapan metode-metode tersebut semakin optimal jika dilakukan bersamaan dengan penggunaan media digital.

\footnotetext{
${ }^{19}$ Ginanjar Rahmat, "Masa Depan Pendidikan Bernama E-Leraning," dalam Nur Janti, dkk, Online! Geliat Manusia dalam Semesta Maya, (Yogyakarta: EKSPRESI Buku LPM EKSPRESI, 2014), cet ke-1, hlm 120-121.

${ }^{20}$ Hamzah B. Uno dan Nina Lamatenggo, Teknologi Komunikasi dan Informasi Pembelajaran, (Jakarta: Bumi Aksara, 2011), cet ke-2, hlm. 60.
} 
FITR AH Jurnal Kajian Ilmu-ilmu Keislaman

Vol. 03 No. 1 Juli 2017

\section{Optimalisasi Perpustakaan Digital}

Perpustakaan bagi lembaga pendidikan Islam mutlak kehadirannya. Perpustakaan tidak hanya berisi kumpulan atau koleksi referensi-refernsi tertulis atau cetak semata. Tetapi harus juga meningkatkan kapasitas serta aksesnya dalam menyediakan referensi digital dalam banyak bidang kelilmuan dari berbagai sumber serta menyediakan informasi yang dapat diakses oleh pengguna maupun masyarakat secara daring (online).

Hadirnya perpustakaan digital ${ }^{21}$ dimaksudkan untuk memudahkan bagi siapapun dalam menelusuri berbagai referensi dan sumber belajar. Kelebihan perpustakaan digital akan sangat membantu dalam pemanfaatan sumber belajar selama 24 jam-7 hari tanpa batas. Lembaga pendidikan Islam dituntut mampu menyediakan perpustakaan secara digital yang dapat diakses oleh peserta didik maupun pihak lain yang berkepentingan.

Optimalisasi perpustakaan digital akan mendukung dalam kelancaran pendidikan Islam. Kendala kesulitan mengakses referensi ilmiah atau informasi secara cetak dapat diantisipasi dengan sumber dan referensi digital. Jika pendidikan Islam ingin tampil dalam menyediakan sumber belajar dan referensi berbagai disiplin maupun multidisiplin keilmuan, maka ketersediaan dan optimalisasi perpusatakaan digital mutlak dikedepankan. Apalagi saat ini begitu banyak referensi yang sifatnya terbuka atau open acces yang dapat dimanfaatkan untuk memperkaya koleksi perpustakaan digital.

Perpustakaan digital menawarkan banyak kelebihan dibandingkan dengan perpustakaan biasa, seperti menghemat ruangan, akses ganda (mutiple acces), tidak dibatasi oleh ruang dan waktu, koleksi dapat berbentuk multimedia, dan biaya lebih murah. ${ }^{22}$ Tentu saja keberadaan perpustakaan digital tidak dengan serta merta meniadakan atau mengesampingkan peran perpustakaan konvensional.

Hal yang tidak boleh diabaikan terkait keberadaan perpustakaan digital adalah melek digital (digital literacy). Peran pustakawaan perlu dioptimalkan dalam upaya melek digital. Perpustakaan umum maupun perpustakaan

${ }^{21}$ Perpustakaan digital adalah perpustakaan yang mengelola semua atau sebagian yang substansi dari koleksi-koleksinya dalam bentuk komputerisasi sebagai bentuk alternatif, suplemen atau pelengkap terhadap cetakan konvensional dalam bentuk mikro material yang saat ini didominasi koleksi perpustakaan. Lihat Abdul Rahman Saleh, Membangun Perpustakaan Digital: Step by Step, (Jakarta: Sagung Seto, 2010), cet ke-1, hlm. 2-4.

${ }^{22}$ Lihat ibid., hlm. 4-5. 
komunitas dapat melakukan penguatan dalam melek digital karena digitalisasi memang membutuhkan budaya baru berupa keterbukaan, kemanfaatan, inklusif, dan merasakan pengalaman menggunakan kemajuan teknologi informasi. ${ }^{23}$

Berbagai langkah strategis di atas perlu didukung segenap pihak dengan menempatkan komitmen yang tinggi dalam mewujudkan pendidikan Islam yang bermutu, baik pada ranah input, proccess, dan output. Yang tidak boleh dikesampingkan dari langkah-langkah strategis pengembangan pendidikan Islam, seperti yang ditawarkan oleh Ali dengan tiga upaya atau aktivitas, yaitu,

1. Menempatkan kembali seluruh aktivitas pendidikan (talab al-ilm) di bawah framework agama.

2. Dalam kerangka paradigma tersebut di atas, perlu adanya sebuah keharusan dalam perimbangan (balancing) antar berbagai disiplin ilmu pengetahuan dalam kurikulum pendidikan.

3. Perlunya dorongan terhadap kebebasan untuk melakukan pengembangan keilmuan secara maksimal. ${ }^{24}$

\section{PENUTUP}

Hadirnya era digital menjadi peluang besar bagi pendidikan Islam untuk dapat mengoptimalkan sumber dayanya dalam melahirkan generasi unggul di berbagai bidang kehidupan. Dengan merancang dan menerapkan strategi jitu dan komprehensif pendidikan Islam diharapkan mampu survive di tengah peradaban dunia serta mampu menunjukkan eksistensinya dengan menawarkan solusi kreatif atas berbagai problem di kancah global yang terjadi di masa kini dan mendatang. Harapan itu tersemat dan menjadi beban moral bagi para pemangku kepentingan pendidikan Islam.

23 Dyah Safitri, "Pustakawan dan Masyarakat Melek Digital," dalam Kompas, Jumat, 10 Februari 2017.

24 Suryadharma Ali, Paradigma al-Qur'an: Reformasi Epistemologi Keilmuan Islam, (Malang: UIN-Maliki Press, 2013), hlm. 153-154. 
FITR AH Jurnal Kajian Ilmu-ilmu Keislaman

Vol. 03 No. 1 Juli 2017

\section{DAFTAR PUSTAKA}

Achmadi, 2008, cet ke-2, Ideologi Pendidikan Islam: Paradigma Humanisme Teosentris, Yogyakarta, Pustaka Pelajar.

Ahmad, Fathoni, Tantangan Pendidikan di Era Digital, Bagaimana Menyikapinya?, http://madrasah.kemenag.go.id/didaktika/96/tantangan-pendidikan-di-eradigital-bagaimana-menyikapinya.html, diakses pada 26 Maret 2017.

Ali, Suryadharma, 2013, Paradigma al-Qur'an: Reformasi Epistemologi Keilmuan Islam, Malang, UIN-Maliki Press.

Arifi, Ahmad, 2010, cet ke-1, Politik Pendidikan Islam: Menelusuri Ideologi dan Aktualisasi Pendidikan Islam di Tengah Arus Globalisasi, Yogykarta, Penerbit Teras.

Azra, Azyumardi, 2012, cet ke-1, Pendidikan Islam: Tradisi dan Modernisasi di Tengah Tantangan Milenium III, Jakarta, Kencana.

Darmawan, Deni, 2012, Teknologi Pembelajaran, Bandung, Remaja Rosdakarya.

Darmawan, Deni, 2013, cet ke-2, Pendidikan Teknologi Informasi dan Komunikasi, Bandung, Remaja Rosdakarya.

Daulay, Haidar Putra, 2012, cet ke-3, Pendidikan Islam dalam Sistem Pendidikan Nasional di Indonesia, Jakarta, Kencana.

Lestari, S. dan Ngatini, 2010, cet ke-1, Pendidikan Islam Kontekstual, Yogyakarta, Pustaka Pelajar.

Muhaimin, 2012, cet ke-2, Pemikiran dan Aktualisasi Pengembangan Pendidikan Islam, Jakarta, Rajawali Pers.

Musfah, Jejen (ed.), 2012, cet ke-1, Pendidikan Holistik: Pendekatan Lintas Perspektif, Jakarta, Kencana.

Nata, Abuddin, 2012, cet ke-1, Kapita Selekta Pendidikan Islam, Jakarta, RajaGrafindo Persada.

Rahmat, Ginanjar, "Masa Depan Pendidikan Bernama E-Leraning," dalam Nur Janti, dkk, 2014, cet ke-1, Online! Geliat Manusia dalam Semesta Maya, Yogyakarta, EKSPRESI Buku LPM EKSPRES.

Safitri, Dyah, "Pustakawan dan Masyarakat Melek Digital," dalam Kompas, Jumat, 10 Februari 2017. 
Saleh, Abdul Rahman, 2010, cet ke-1, Membangun Perpustakaan Digital: Step by Step, Jakarta Sagung Seto.

Suryadi, Ace, 2014, cet ke-1, Pendidikan Indonesia Menuju 2025; Outlook: Permasalahan, Tantangan \& Alternatif Kebijakan, Bandung, Remaja Rosdakarya.

Uno, Hamzah B. dan Nina Lamatenggo, 2011, cet ke-2, Teknologi Komunikasi dan Informasi Pembelajaran, Jakarta, Bumi Aksara. 